\title{
PELATIHAN DESAIN GERABAH DENGAN TEKNIK BATIK BERSAMA GURU DAN MURID DALAM RANGKA REVITALISASI GERABAH TRADISIONAL GALOGANDANG SUMATERA BARAT
}

\author{
Hendra1), Desi Trisnawati2), Armen Nazaruddin $^{3}$ ) \\ 1)2)3)Program Studi Seni Kriya Fakultas Seni Rupa dan Desain Institut Seni Indonesia Padangpanjang \\ Jl. Bahder Johan Padangpanjang Sumatera Barat/27128 \\ Email :doankhendra7@gmail.com ${ }^{13}$, desiant35@gmail.com²), armennazaruddin35@gmail.com ${ }^{3)}$
}

\begin{abstract}
ABSTRAK
Pelatihan di SD dan SMP sekitar Galogandang dilakukan untuk menumbuhkan kebanggaan generasi muda terhadap produk budaya lokal. Apalagi pembuatan gerabah di Galogandang sekarang ini hanya didominasi oleh ibu-ibu yang lanjut usia. Sedangkan belum tampak adanya generasi muda yang berminat melanjutkan dan mengembangkannya. Jika hal ini dibiarkan berlanjut, maka lama kelamaan gerabah di Galogandang bisa tinggal sejarah.

Dibutuhkan suatu usaha untuk menggugah minat generasi muda terhadap gerabah di Galogandang. Salah satunya dengan pelatihan desain gerabah dengan motif batik khas Minangkabau. Kegiatan pelatihan yang tergolong baru untuk wilayah Sumatera Barat ini ditujukan untuk mempopulerkan gerabah tradisional yang dipadukan dengan motif kontemporer yaitu batik khas Minangkabau. Kegiatan ini dinilai efektif untuk mendongkrak popularitas gerabah tradisi dan mempromosikan motif batik khas Minangkabau yang belum banyak dikenal masyarakat. Pelatihan ini mengajarkan bagaimana membuat motif batik khas Minangkabau dengan menggunakan canting batik sehingga produk yang dihasilkan lebih menarik.

Mendekorasi gerabah dengan teknik ini bisa menjadi solusi bagi pengrajin gerabah dalam memasarkan produk gerabahnya yang selama ini dibuat tanpa ada motif hias. Dengan kegiatan ini diharapkan akan bisa mempopulerkan kembali gerabah Galogandang dengan wajah baru yang lebih kreatif. Kedepannya pengrajin juga bisa membuat beragam bentuk desain baru dari gerabah untuk disesuaikan dengan konsep motif kreasi yang dibuat.
\end{abstract}

Kata kunci : Gerabah, Desain, Batik Khas Minangkabau

\section{PENDAHULUAN}

\subsection{Latar belakang}

Sistem pendidikan sekarang yang lebih menekankan pembentukan karakter perlu ditunjang dengan pengenalan budaya bangsa. Selanjutnya kita sama-sama mengharapkan bahwa pendidikan itu akan hidup dan menghidupi kebudayaan sebagai pondasinya sehingga budaya luhur bangsa ini bisa diapresiasi dengan maksimal oleh generasi penerusnya. Salah satu gebrakan yang ditempuh pemerintah untuk mengembangkan pendidikan seni adalah dengan rutin mengadakan perlombaan siswa dibidang seni. Kegiatan yang menjadi contoh adalah Festival Lomba Seni Sastra Nasional (FLS2N) yang diadakan mulai dari tingkat SD, SMP dan SMU sederajad. Lomba bidang seni seperti ini tentunya akan memacu para siswa didik untuk berprestasi didalam bidang bidang seni yang diperlombakan dan menggugah kebanggaan mereka terhadap budaya daerah.

Kebanggaan siswa sekolah terhadap budaya lokal juga perlu dikembangkan di Jorong Galogandang. Daerah yang secara administratif merupakan bagian Nagari III Koto, Kecamatan Rambatan, kabupaten Tanah Datar. Dahulunya, sesuai dengan UU No. 5 Tahun 1979 Tentang Sistem Pemerintahan Desa di Propinsi Sumatera Barat, Desa Galogandang adalah desa. Ketika sistem pemerintahan di Sumatera Barat kembali ke Nagari maka Galogandang kembali menjadi sebuah jorong dari Nagari III Koto. Jorong Galogandang terletak pada ketinggian 540 meter diatas permukaan laut denga luas wilayah sekitar 350 hektare. 
Jorong Galogandang yang terletak di Nagari III Koto Kecamatan Rambatan dikenal sebagai salah satu daerah penghasil kerajinan gerabah tradisional untuk wilayah Kabupaten Tanah Datar.

Berbagai bentuk gerabah seperti periuk, guci dan lain sebagainya dihasilkan oleh penduduk untuk berbagai keperluan. Namun seiring perkembangan zaman, jumlah pengrajin gerabah di Galogandang menurun drastis. Salah satu penyebabnya adalah kurangnya minat dari generasi muda untuk melanjutkan usaha membuat gerabah, dan lebih memilih untuk pergi merantau keluar daerah. Fenomena ini terus berlanjut sehingga pengrajin yang tinggal sekarang hanya mereka yang tua saja. Sedangkan anak-anak mereka tidak dikenalkan dengan kerajinan gerabah ini yang beberapa dasawarsa yang lalu pernah menjadi pekerjaan mayoritas penduduk Galogandang. Jika hal ini terus berlanjut, diperkirakan dalam beberapa tahun kedepan akan sulit menemukan kerajinan gerabah yang dibuat oleh warga Galogandang.
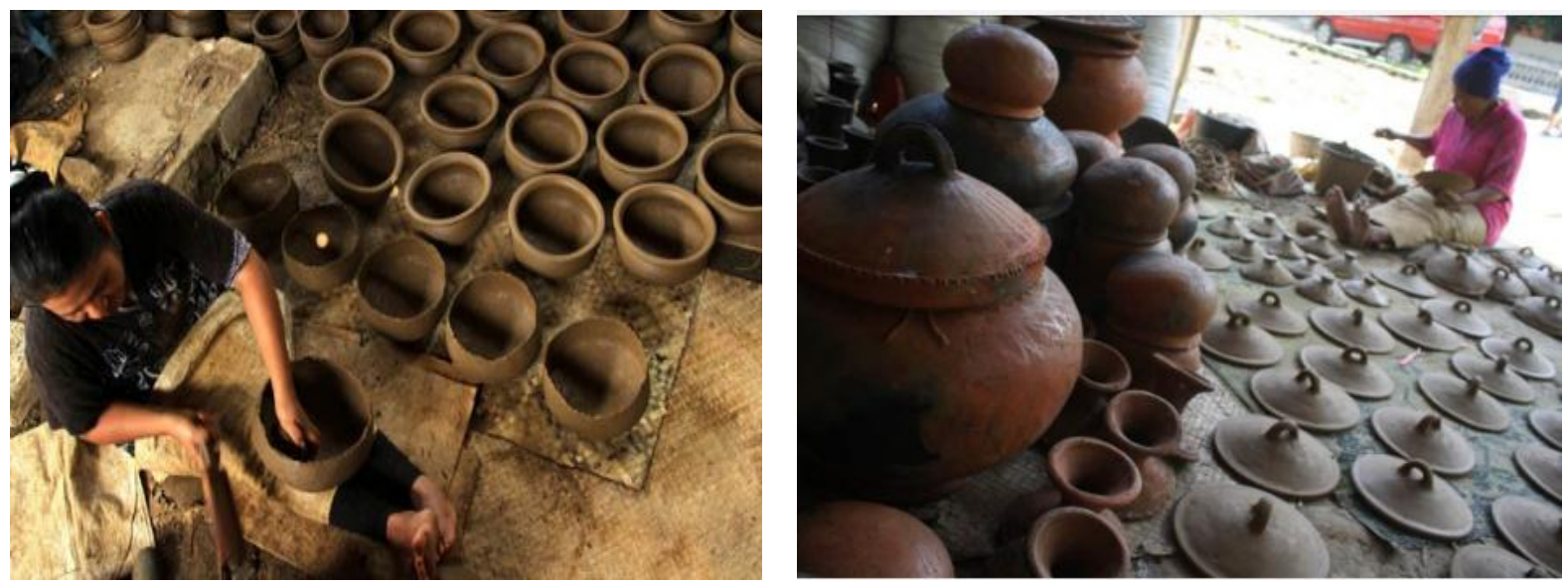

Gambar 1. Kegiatan perempuan Galogandang membuat gerabah

Untuk menumbuhkan minat dan kecintaan dari generasi muda terhadap gerabah Galogandang tersebut, maka perlu diadakan suatu kegiatan pelatihan desain gerabah dengan motif batik khas Minangkabau disekolah. Desain adalah suatu perwujudan dari suatu gagasan atau hasil karya yang bersifat inovatif dan kreatif dari seseorang atau lebih untuk menciptakan sesuatu pola tertentu dengan cara menentukan serta memperincikan setiap bagian elemen atau komponen dari pola tersebut serta antara hubungannya satu dengan yang lain, sehingga tersusun suatu pola dari bentuk yang merupakan suatu keseluruhan. (Prawira, 1983:1).

Kegiatan ini ditujukan untuk menggugah kepedulian generasi muda terhadap kerajinan gerabah yang terancam punah. Gerabah tersebut nantinya dihiasi dengan motif batik khas Minangkabau yang unik. Selain itu motif batik khas Sumatera Barat memang sedang digalakkan untuk dikembangkan oleh Pemerintah Provinsi Sumatera Barat untuk menjadi ikon daerah. (Wawancara dengan Rionald, Sekretaris Dekranasda Provinsi Sumatera Barat: Desember, 2016).

\subsection{Masalah}

Pengrajin tradisional Galogandang mendapatkan keahlian membuat gerabah secara turun temurun. Hal ini sudah dimulai semenjak puluhan tahun yang lalu dimana keahlian membuat gerabah diwariskan secara turun temurun. Hal ini seperti yang disampaikan oleh Wati ( 50 tahun) bahwa dia mewarisi kemampuan membuat gerabah dari orangtuanya yang juga membuat gerabah. Namun sekarang fenomena seperti itu mulai ditinggalkan dimana anaknya tak mau mengikuti jejaknya menjadi pengrajin gerabah. Tiga orang anaknya terdiri dari dua orang laki laki dan satu orang perempuan tak ada yang menjadi pengrajin gerabah. Anak laki-lakinya memilih merantau dan berdagang sedangkan anak perempuannya juga mengikuti suami tinggal di Kota Bukittinggi. Wati mengatakan bahwa anaknya tak ada yang mau mengikuti jejaknya menjadi pengraji gerabah dikarenakan secara ekonomi, profesi membuat gerabah tidak bisa mencukupi butuhan hidup sehari-hari. Hal ini dikarenakan harga gerabah berbentuk balango ditingkat pengrajin hanya sekitar Rp. 7.000 sampai Rp. 12.000. Harga ini dirasakan tidak sebanding dengan waktu pembuatan yang relatif lama dan proses pembuatannya yang cukup melelahkan. 
Kondisi seperti ini yang membuat rata-rata pengrajin gerabah sekarang hanya wanita usia 40 tahun keatas yang yang menjadikan pekerjaan ini sebagai pengisi waktu luang. Persoalan yang telah berlangsung bertahun tahun ini tentunya mengancam eksistensi dan keberlangsungan kerajinan gerabah Galogandang. Jika fenomena ini terus dibiarkan, bisa jadi sepuluh atau duapuluh tahun kedepan kerajinan gerabah Galogandang hanya tinggal nama. Perlu diupayakan suatu kegiatan untuk menggugah ketertarikan dan kebanggaan dari generasi muda Galogandang terhadap budaya lokal tersebut. Perlu diupayakan suatu startegi kegiatan untuk menumbuhkan minat dan ketertarikan dari generasi muda Galogandang terhadap produk gerabah tersebut. Salah satunya adalah dengan membuat kegiatan pelatihan desain gerabah dengan motif batik yang akan menambah nilai jual dari gerabah tersebut.

Dengan diadakannya pelatihan mendesain gerabah dengan motif batik khas Minangkabau ini, maka siswa akan dikenalkan dengan budaya daerahnya sendiri dan diharapkan akan menumbuhkan kecintaan terhadap kesenian lokal. Pelatihan nantinya akan diberikan kepada siswa Sekolah Dasar (SD) dan Sekolah Menengah Pertama (SMP) disekitar wilayah Galogandang. Apalagi perlombaan desain batik merupakan kegiatan yang rutin diadakan setiap tahun dalam FLS2N. Hal ini tentunya dapat memacu kreatifitas dan kecintaan generasi muda terhadap budaya sendiri. Batik adalah kain tekstil hasil pewarnaan, pencelupan rintang menurut corak khas batik Indonesia dengan menggunakan lilin batik sebagai zat perintang. (Yosef, 2011: 73-81). Sedangkan dalam kegiatan ini proses membatik tetap dilakukan dengan menggunakan lilin batik dan canting, namun media yang digunbakan bukan kain atau sejenisnya, namun gerabah itu sendiri yang menjadi objek membatik. Sehingga proses membatik diatas permukaan gerabah akan menjadi pengalaman tersendiri bagi siswa dan guru serta menanamkan kecintaan mereka terhadap gerabah tradisional Galogandang itu. Batik Mempunyai dua komponen utama yaitu warna dan garis. Kedua komponen inilah yang membentuk batik menjadi indah dan menawan. (Wulandari, 2011: 76). Jadi pada intinya, selama dua komponen utama tersebut ada, tidaklah menjadi masalah apapun media yang digunakan, baik itu kain ataupun gerabah dan media lainnya yang mungkin bisa diaplikasikan untuk motif batik itu sendiri.

\section{METODE}

\subsection{Proses pelaksanaan kegiatan}

Kegiatan yang dilaksanakan untuk menumbuhkan minat generasi muda Galogandang terhadap gerabah adalah dengan pelatihan desain. Agar kegiatan yang direncanakan ini dapat terlaksana dengan baik dan mencapai hasil yang diharapkan, perlu dirancang suatu proses atau metode pelaksanaan yang tepat dan sesuai dengan tujuan yang dibuat. Metode pelaksanaan kegiatan pelatihan ini adalah eksplorasi media dan model sehingga didapatkan hasil produk yang maksimal. Untuk itu dilaksanakan beberapa tahapan sehingga materi yang diberikan bisa dipahami oleh peserta seperti (1) metode ceramah untuk menyampaikan materi yang bersifat teoritis, (2) metode demonstrasi yang digunakan untuk memperlihatkan cara dan teknik yang digunakan, serta (3) metode eksperimen yang digunakan untuk memperoleh pengalaman tentang teknik dan hasil eksplorasi metode aplikasi desain yang dipakai dan yang selanjutnya adalah (4) metode resitasi atau pemberian tugas. Metode seperti ini dinilai cukup efektif untuk memberikan pemahaman dan transfer ilmu kepada mitra yang terdiri dari guru dan murid. Metode ceramah diberikan pada pertemuan awal yang meliputi pemberian pengantar teoretis menegani gerabah, desain gerabah, serta pemahaman mengenai batik serta motif batik khas Minangkabau. Untuk lebih memberikan pemahaman kepada siswa, kegiatan ini juga dilengkapi dengan metode presentasi dan slideshow beberapa model gambar untuk contoh dan membuka wawasan dari peserta.

Metode selanjutnya adalah demonstrasi dimana bertujuan untuk memperlihatkan proses dari mendesain dan aplikasi desain ke media gerabah. Untuk langkah awal dicontohkan bagaimana membuat desain pada media kertas sehingga lebih mudah untuk diikuti oleh peserta. Setelah itu baru dilanjutkan dengan mengaplikasikan desain dari media kertas ke gerabah yang memiliki permukaan tidak datar dan tentunya akan lebih sulit daripada membuat desain diatas media kertas. Pada proses ini digunakan beberapa teknik yaitu teknik aplikasi desain batik dengan kuas cat air dan aplikasi desain batik dengan membatik langsung diatas permukaan gerabah dengan 
menggunakan canting dan pewarnanya menggunakan malam. Teknik dan metode ini yang perlu ditekankan dan diperkenalkan kepada peserta karena masih baru dan belum begitu populer dimasyarakat.

Proses selanjutnya adalah eksperimen dari berbagai bentuk motif batik khas Minangkabau yang akan diaplikasikan di media gerabah. Pemilihan jenis motif dan kesesuaian dengan bentuk gerabah juga menjadi hal yang harus dipertimbangkan. Tujuannya agar gerabah yang diaplikasikan motif batik tersebut memiliki nilai estetis dan filosofi yang kuat sehingga memiliki nilai jual yang tinggi juga. Proses yang terakhir adalah metode resitasi atau pemberian tugas kepada peserta untuk muali membuat gerabah dengan desain batik tersebut. Setiap langkah dan proses yang dilakukan harus didampngi sehingga tujuan dari kegiatan ini dapat tercapai denga baik dan peserta bisa memahami setiap proses membatik diatas gerabah tersebut dengan baik.

\subsection{Teknik Pengumpulan data}

Untuk memperoleh data yang akurat dilapangan mengenai kondisi yang terjadi dilaksanakan beberapa metode antara lain :

2.2.1. Metode observasi

Kegiatan ini bertujuan untuk mendapatkan data langsung dan riil dari lapangan. Dengan metode ini penulis melakukan pengamatan awal terlebihdahulu mengenai kondisi gerabah Galogandang dan bagaimana tingkat apresiasi masyarakat sekitar terhadap kerajinan itu sendiri.

2.2.2. Metode Wawancara yang bertujuan untuk mendapatkan data langsung dari narasumber yang berhubungan dengan data yang ingin diperoleh. Metode wawancara ini dilakukan kepada beberapa narasumber yang berbeda profesi dan bidangnya sehingga akan memperoleh data yang lebih akurat.

2.2.3. Pengumpulan data yang dilakukan dengan mendokumentasikan data tersebut melalui foto atau video. Data dari foto dan video nantinya akan menggambarkan lebih jelas tentang kondisi yang ada dilapangan.

2.2.4. Studi Pustaka yang dilakukan mendapatkan data dan informasi tambahanan dari buku atau artikel yang mendukung. Studi pustaka perlu dilakukan untuk mendukung keilmiahan data dan pada saat analisis data nantinya.

\subsection{Lokasi, waktu dan durasi kegiatan}

Kegiatan PKM yang dilaksanakan bertujuan untuk membangkitkan kecintaan dari generasi muda terhadap gerabah Galogandang. Untuk itu dalam kegiatan ini yang disasar adalah siswa SD dan SMP yang ada disekitar Galogandang yang nantinya akan menjadi cikal bakal penerus kerajinan Galogandang ini. Ditangan generasi muda inilah eksistensi gerabah tradisional Galogandang ini ditentukan. Pada kegiatan ini yang dipilih menjadi lokasi pengabdian adalah SDN 06 Nagari III Koto dan SMPN 1 Rambatan.

Untuk menyukseskan kegiatan PKM ini perlu dilakukan upaya pendekatan dengan mitra untuk mengetahui berbagai permasalahan yang ada dilapangan terkait kegiatan ini. Untuk itu dilakukan diskusi dengan Kepala Sekolah dari SDN 06 Galogandang dan SMPN 1 Rambatan mengenai renacana kegiatan dan potensi serta kontribusinya bagi siswa dan juga masyarakat sekitar. Setelah melalui diskusi didapatkan permasalahan antaralain prestasi siswa dalam kegiatan desain batik dan membatik masih rendah serta kurangnya minant dari generasi muda di Galogandang untuk mengembangkan gerabah tradisional Galogandang. Oleh karena itu diusulkan untuk membuat kegiatan pelatihan desain gerabah dengan teknik yang berbeda dan tentunya akan menggugah rasa ingin tahu dari peserta yaitu denganmemmbuat desain batik diatas media gerabah.

Kegiatan ini tentunya belum familiar di kalangan guru ataupun siswa akrena mereka biasanya membatik dengan media kain dan gerabah yang selama ini mereka kenal jarang sekali ada desainnya. Hanya gerabah polos tanpa ada ornamentasinya. Melalui diskusi dan memberikan gambaran yang komprehensif dengan kepala sekolah tersebut, akhirnya pihak sekolah setuju dengan kegiatan PKM ini dan tentunya disertai harapan agar kegiatan ini cepat terlaksana dan bisa memberikan kontribusi nyata bagi minat siswa terhadap gerabah tradisi dan gerabah Galogandang 
ini bisa kembali populer dikalangan masyarakat pendukungnya. Kegiatan ini dilaksanakan dalam jangka waktu 8 bulan semenjak bulan April sampai November 2018. Kegiatan ini dimulai dengan survei lapangan mengenai kondisi lapangan dan pemasalahan yang ada sampai terlaksananya kegiatan pelatihan.

Setelah program PKM ini terlaksana sesuai dengan jadwal yang direncanakan, maka diperlukan suatu kegiatan evaluasi menyeluruh apakah kegiatan ini sesuai dengan target yang direncanakan sebelumnya. Evaluasi kegiatan perlu dilakukan untuk meminimalisasi ketidaksesuaian antara rencana kerja dan hasil yang dicapai. Evaluasi yang direncanakan antara lain dengan melakukan kontrol terhadap kegiatan yang telah dilakukan disekolah. Dengan mengadakan diskusi dengan pihak sekolah terkait tindak lanjut dari kegiatan pelatihan desain batik ini. Target yang diharapkan tentunya adanya prestasi yang diraih oleh siswa dari perlombaan batik yang diikuti dalam kompetisi seperti FLS2N. Selain itu perlu juga ditinjau bagaimana penerapan aplikasi dari metode desain batik ini di tingkat pengrajin yang ikut serta dalam kegiatan ini. Apakah ada tindak lanjut dari mereka atau kendala yang mereka hadapi dilapangan yang tentunya dicarikan solusi yang terbaik. Pengembangan bentuk dan ragam gerabah yang dihasilkan tentunya akan bisa meningkatkan pendapatan pengrajin dan popularitas gerabah Galogandang kembali ditingkatkan.

Pihak sekolah juga diharapkan berperan aktif dalam mempopulerkan desain gerabah dengan motif khas Minangkabau ini ditingkat institusi pendidikan seperti sekolah sekolah yang ada disekitarnya dan juga dengan instansi terkait seperti Dinas Pendidikan, sehingga kegiatan yang dipelopori oleh SDN 06 Galogandang dan SMPN 1 Rambatan ini menjadi populer ditingkat SD dan SMP se-KabupatenTanah Datar. Harapan lebih lanjut adalah masuknya kegiatan pengembangan kreatifitas siswa ini kedalam kegiatan ekstrakurikuler disekolah yang bermuatan lokal dan mengembangkan potensi budaya daerah. Selain itu sosialisasi dan pengembangan motif untuk batik khas Minangkabau akan terus berlanjut dan semakin beragam sehingga kekayaan budaya Minangkabau ini Kegiatan pelatihan desain gerabah dengan teknik batik yang dilaksanakan dimulai dengan beberapa tahapan yang tersistematik sesuai dengan yang telah dijabarkan pada BAB III mengenai pelaksanaan kegiatan. Kegiatan dilaksanakan dengan jadwal yang sudah disepakati dengan guru sehingga dapat diikuti oleh peserta. Kegiatan ini dimulai dengan tahapan pembelajaran mengenai cara membuat desain ornamen sederhana untuk siswa SD dan SMP. Dikarenakan siswa SD dan SMP memiliki kemaampuan yang berbeda, maka target yang dibebankan kepada mereka juga berbeda yang disesuaikan dengan kemampuan yang mereka miliki. Aplagai kemampuan menggambar dan mendesain merupakan kegiatan yang tak bisa ditargetkan sama untuk masing masing peserta, namun setiap peserta akan memiliki kemampuan yang berbeda.

Untuk siswa SD diberikan dasar tentang membuat desain dengan media kertas dan dengan pewarna crayon. Mereka akan ditugaskan untuk membuat desain sederhana sampai ketingkatan sedikit rumit untuk menjadi desain gerabah. Tahapan dari membuat desain diatas kertas, kemudian dilanjutkan dengan membuat desain diatas media kain batik dan terakhir baru membuat desain diatas media gerabah. Tahapan tersebut tentunya memiliki tingkat kesulitan yang semakin komplit dan hal ini yang harus dilalui oleh peserta sampai ke tahap akhir nantinya.

Untuk siswa SMP pada prinsipnya juga akan melalui tahapan yang sama dengan siswa SD dimana mereka akan mulai membuat desain sederhana diatas media kertas, yang kemudian dilanjutkan dengan mencanting diatas media kain. Langka terakhir mereka juga akan melakukan kegiatan mencanting di media gerabah dengan tingkat kesulitan yang lebih tinggi. Hal ini perlu mereka lalui agar mereka merasakan tahapan proses dari mudah ke suli secara bertahap. Target desain yang dibebankan kepada mereka juga sedikit lebih rumit dari yang dibuat oleh siswa SD. Hal ini sesuai juga diukur dengan kemampuan yang mereka miliki. Keseluruhan siswa SD dan SMP ini disaring dari beberapa lokal yang ada untuk kemudian di pilih sebanyak 10 sampai 15 orang per sekolah untuk bisa mengikuti tahapan pelatihan lebih lanjut. Hal ini bertujuan untuk memudahkan pembimbingan dan koordinasi antara tim dengan peserta. 


\section{PEMBAHASAN}

\subsection{Koordinasi kegiatan}

Untuk menyukseskan pelaksanaan kegiatan pelatihan ini, maka dirancang beberapa tahapan untuk memudahkan penyampaian materi sehingga bisa diterima oleh peserta. Secara garis besar langkah tersebut antara lain (1) Koordinasi, (2) pelaksanaan dan (3) evaluasi. Langkah koordinasi yang dimaksud adalah penyampaian rencana kegiatan ini oleh ketua tim pengabdi ke guru di SD dan SMP yang ada. Dalam koordinasi ini diadakan diskusi singkat mengenai rencana kegiatan dan juga hasil yang ingin dicapai nantinya. Dalam kegiatan ini juga diadakan diskusi dan saling dengar pendapat antara tim dan guru mengenai startegi pelaksanaan kegiatan ini nantinya.

\subsection{Pelaksanaan kegiatan}

Sesuai dengan rencana awal dan permasalahan yang dihadapi dimana kurangnya minat generasi muda untuk mengembangkan produk gerabah Galogandang, maka siswa SD dan SMP diperkenalkan metode dan cara meningkatkan nilai jual produk tersebut dengan memberikan ornamen atau desain gerabah dengan teknik batik. Membuat desain batik diatas media gerabah tentu merupakan hal yang baru bagi masyarakat Galogandang yang selama ini produk yang mereka hasilkan hanya berubah gerabah polos yang tanpa hiasan sehingga terjual dengan harga yang murah. Harga murah tersebut kadang sangat miris jika dibandingkan dengan berbagai tahapan dan proses yang dilalui dari pengolahan tanah sampai menjadi tembikar.

Untuk mendukung pelaksanaan kegiatan ini maka dirancang proses transfer ilmu ini antara lain (1) pembuatan desain ornamen tradisional Minangkabau diatas media kertas (2) pembuatan desain diatas kain batik dengan canting. (3) pembuatan ornamen di media gerabah dengan teknik lukis menggunakan kuas dan yang terakhir (4) adalah membuat motif batik khas Minangkabau diatas gerabah dengan teknik batik.

Tahapan kegiatan diatas dimulai dengan presentasi secara umum mengenai pentingnya menjaga eksistensi Gerabah Galogandang yang telah hadir selama puluhan tahun, namun sekarang harus menghadapi derasnya arus globalisasi yang mengancam penggunaan gerabah tradisional tersebut. Dalam presentasi itu juga disampaikan bahwa minat generasi muda Galogandang untuk mengembangkan produk Galogandang tersebut sangat minim sekali dimana pengrajin gerabah tradisional Galogandang saat ini rata rata sudah diatas umur 40 tahun. Dan belum nampak adanya generasi muda yang berminat menekuninya. Selain itu juga disampaikan bahwa dengan mengembangkan desain gerabah Galogandang baik dari segi bentuk ataupun ornamentasi yang ada, maka produk tersebut bisa memiliki nilai jual yang lebih tinggi dan banyak diminati oleh pasar. Hal seperti inilah yang mendasari kegiatan pengembangan desain gerabah Galogandang tersebut sehingga nantinya bisa mendongkrak nilai jualnya dan menambah pendapatan pengrajin.
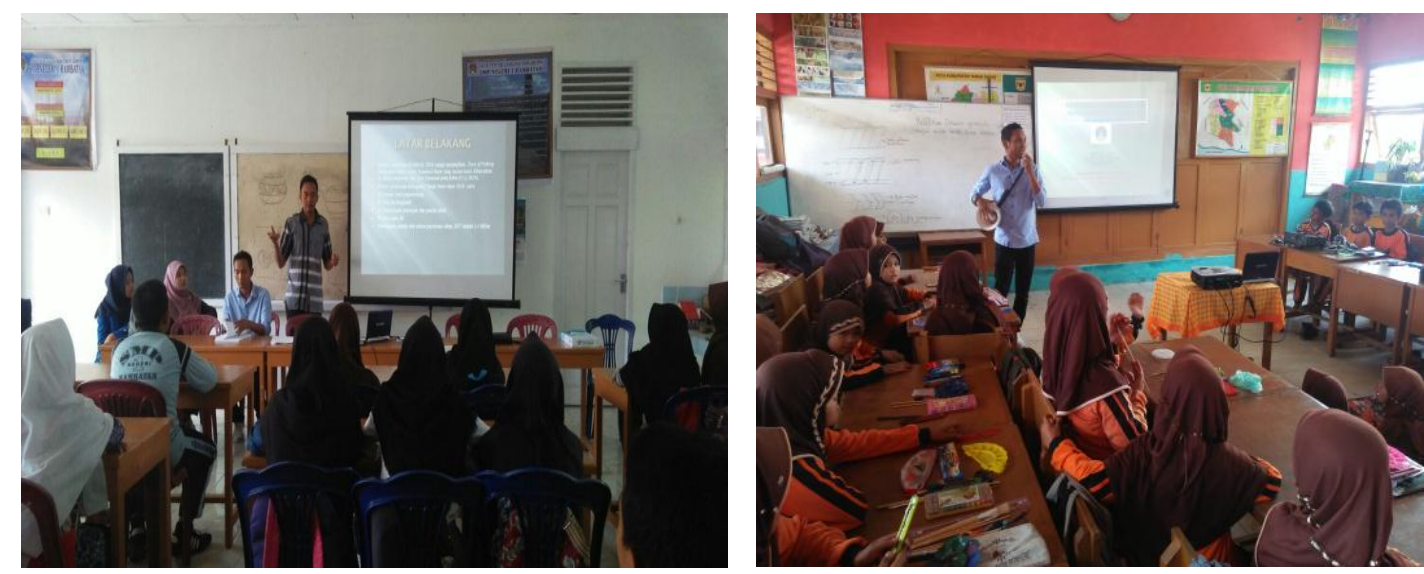

Gambar 2. Presentasi sekolah di SD dan SMP 
Setelah kegiatan presentasi dilanjutkan dengan kegiatan diskusi dengan guru dan murid mengenai materi yang disampaikan. Dalam kegiatan ini juga dilaksanakan kegiatan diskusi dan tanya jawab mengenai bagaimana harapan dan pandangan peserta terhadap eksistensi gerabah Galogandang. Dari diskusi dan tanya jawab ini dapat disimpulkan bahwa mereka tidak pernah berfikir bahwa Gerabah Galogandang tersebut bisa memiliki prospek dan potensi ekonomi yang begitu besar jika dikembangkan. Mereka hanya menganggap bahwa gerabah tersebut hanya digunakan untuk memasak gulai secara tradisi dan tak memiliki potensi yang menjanjikan untuk dikembangkan.

Kegiatan selanjutnya yang dilakukan adalah pelatihan desain gerabah dengan memperkenalkan motif tradisional Minangkabau. Kegiatan ini dilakukan secara marathon sehingga siswa tidak kehilangan momentum untuk kegiatan tersebut. Pelatihan dilakukan selama seminggu untuk melihat sejauhmana kemampuan dari siswa tersebut membuat desain. Pelatihan membuat desain ini dilakukan disore hari ketika anak anak selesai jam sekolah dan kegiatan ini dilakukan sebagai bagaian dari ekstra kurikuler sekolah. Dari hari pertama hingga hari kelima progres dan kemajuan siswa dalam membuat desain dipantau. Selain itu kelenturan tangan dalam mendesain juga diperhatikan. Untuk siswa SD di hari pertama jumlah peserta mencapai 50 orang anak. Dihari kedua jumlahnya disaring menjadi 20 anak terpilih. Dihari ketiga jumlahnya disaring lagi menjadi 15 anak terpilih yang dianggap bisa mengikuti kegiatan lanjutan untuk membatik. Di hari keempat kegiatan dilanjutkan dengan latihan membatik karena siswa dan guru sudah penasaran bagaimana cara membatik. Apalagi di SDN 06 Galogandang belum pernah dilakukan kegiatan membatik. Siswa dan guru dibimbing untuk mengikuti kegiatan membatik dari proses membuat desain diatas kain dan dilanjutkan dengan kegiatan mencanting. Setelah mencanting dilanjutkan dengan mewarnai dan melorod dengan menggunakan 1 warna sehingga nampak hasil dari kegiatan tersebut.
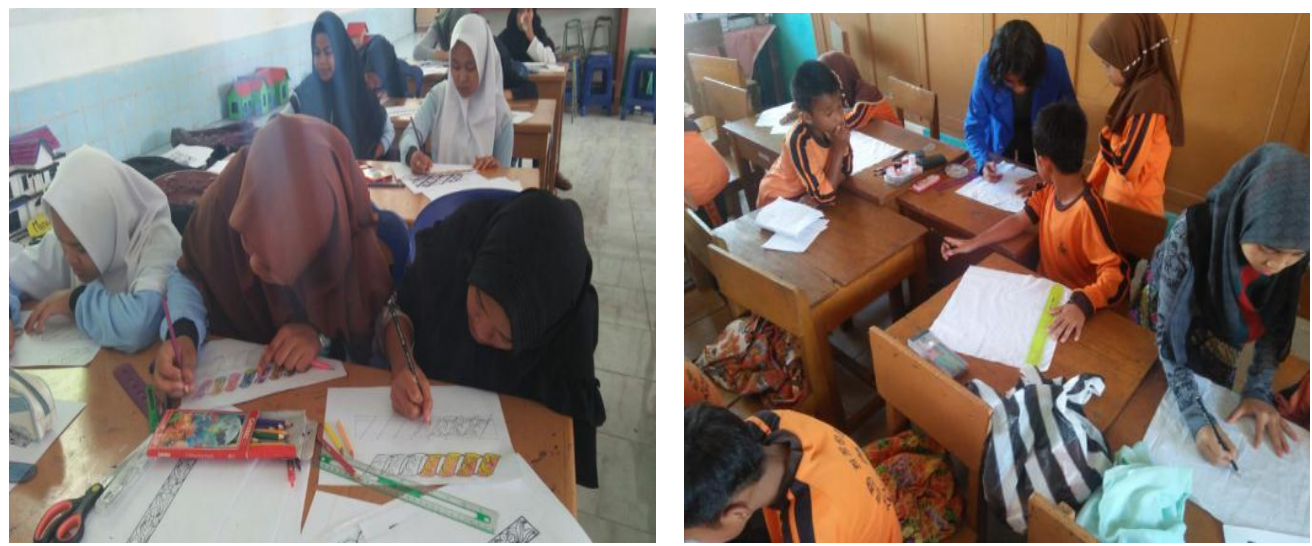

Gambar 3. Kegiatan Mendesain Motif tradisi
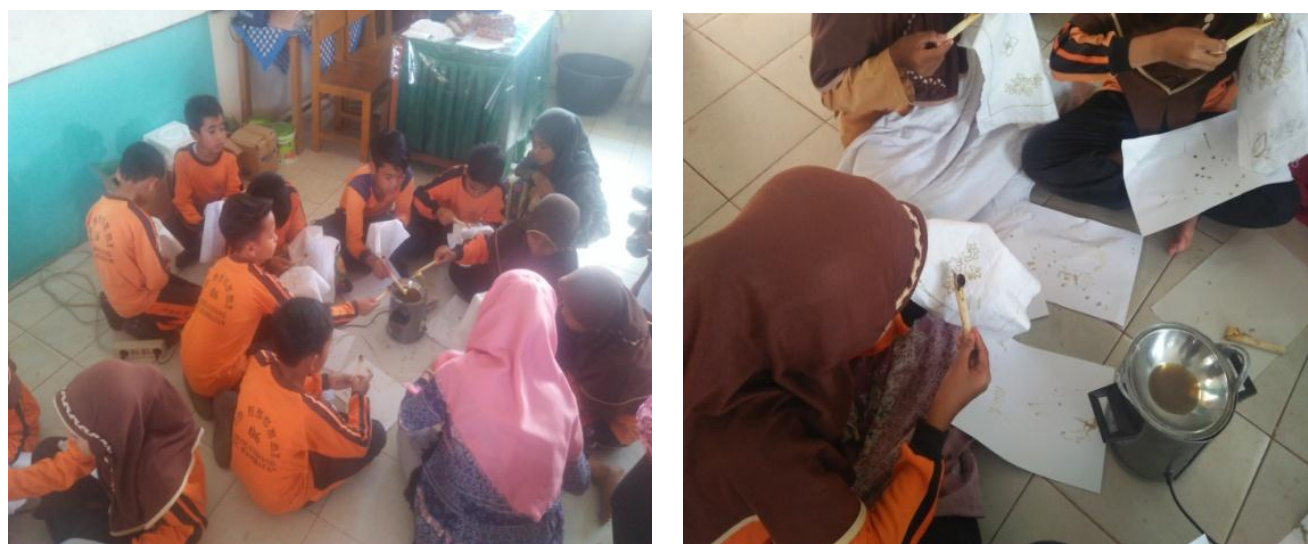

Gambar 4. Latihan Membatik di Kain 

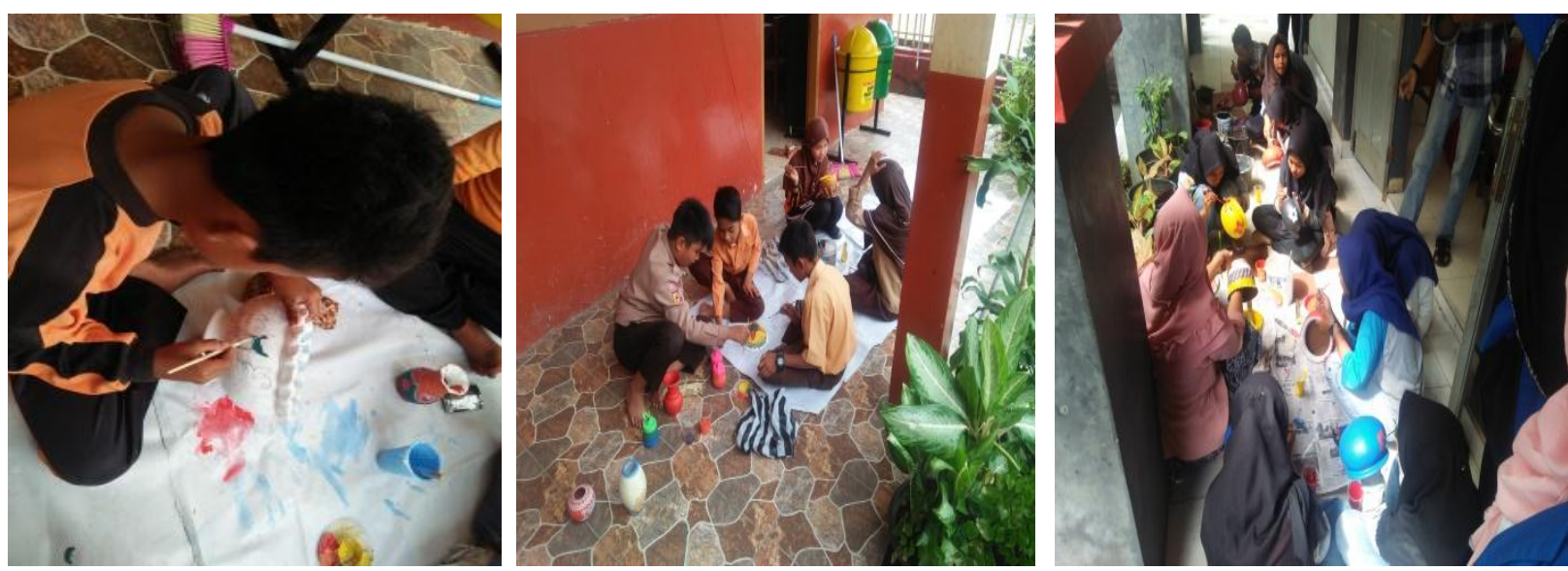

Gambar 5. Latihan Melukis diatas Gerabah
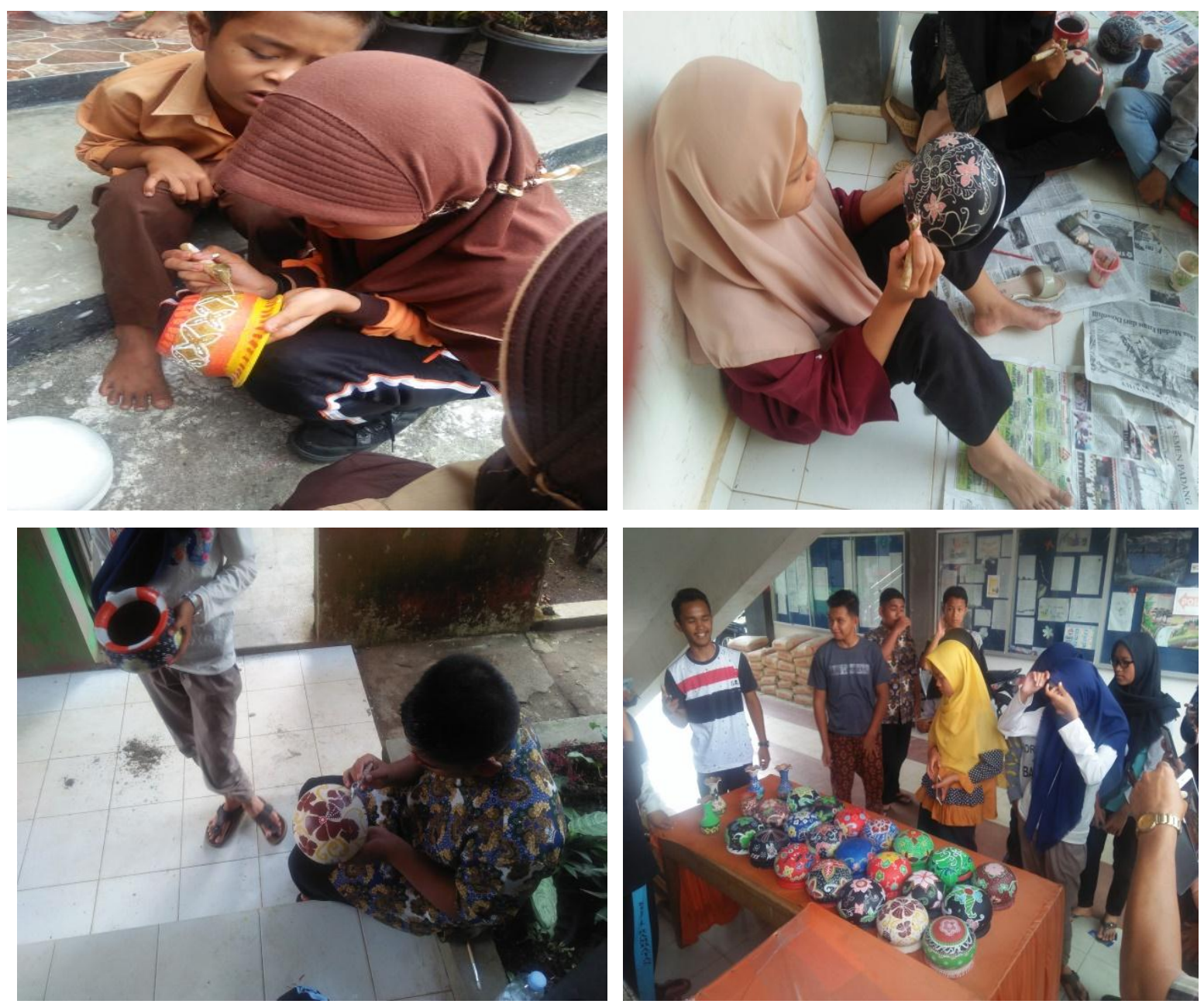

Gambar 6. Kegiatan Mencanting/membatik di Permukaan gerabah

\section{KESIMPULAN}

Dengan selesainya kegiatan pelatihan desain gerabah di SD dan SMP Galogandang tersebut, maka diharapkan generasi muda di Galogandang akan memiliki kepedulian terhadap gerabah Galogandang. Hal ini karena selama ini generasi muda tidak memiliki minat dan keinginan untuk mengembangkan gerabah tradisional tersebut. Hal ini membuat gerabah tradisional Galogandang semakin sulit untuk berkembang. Walaupun sudah hadir selama puluhan tahun, namun popularitas gerabah tradisi tersebut seperti tertutupi oleh beragam produk modern berbahan plastik atau aluminium yang dinilai lebih praktis dan awet. Sedangkan produk gerabah galogandang dianggap 
sebagai produk lama yang ketinggalan zaman. Kegiatan pelatihan yang telah terlaksanan ini dapat berjalan sesuai dengan rencana yang telah disusun sebelumnya. Kegiatan mendesain gerabah ini dapat meningkatkan minat ketertarikan dari peserta

Namun dengan adanya kegiatan pelatihan dan pengembangan desain gerabah tersebut, diharapkan minat generasi muda untuk mengembangkan produk gerabah lokal tersebut semakin terpacu. Hal ini dikarenakan besarnya peluang usaha dan ekonomi yang dijanjikan. Dengan mendesain gerabah dengan desain yang menarik akan meningkatkan nilai jual dipasaran. Selain itu produk gerabah dengan desain batik khas Minangkabau juga akan menarik perhatian dari wisatawan. Mereka akan rela merogoh koceknya untuk mendapatkan cendramata khas dari Minangkabau yang terbuat dari gerabah. Tentunya produk gerabah dengan desain batik khas minangkabau belum ada yang dijual dipasaran. Dengan mengkreasikan beragam motif, diharapkan generasi muda yaitu siswa SD dan SMP yang dibantu dengan gurunya akan menghasilkan beragam desain yang menarik yang nantinya bisa diaplikasikan untuk gerabah Galogandang. Hal ini akan meningkatkan popularitas gerabah Galogandang di masyarakat.

Diakhir kata penulis mengucapkan terimakasih kepada Direktorat Riset dan Pengabdian Masyarakat (DRPM) Kemenristek DIKTI yang telah memberikan dukungannya melalui Program Kemitraan Masyarakat sehingga kegiatan ini dapat terlaksana dengan baik. Selanjutnya diharapkan agar kegiatan ini bisa menjadi pionir dan rujukan bagi kegiatan lain yang sejenis untuk bisa meningkatkan potensi dan pemberdayaan masyarakat.

\section{DAFTAR PUSTAKA}

Mulyasa. 2006. Menjadi Guru Profesional. Remaja Rosdakarya.Bandung.

Prawira, N. Ganda \& Dharsono. 2003. Pengantar Estetika dalam Desain Seni Rupa. Departemen Pendidikan Nasional. Bandung.

Wulandari, Ari. 2011. BatikNusantara Makna Filosofis Cara Pembuatan Dan Industri Batik. CV Andi Offset. Yogyakarta.

Yosef, Gde TJ. 2011. Filsafat Sebagai Kajian Dasar Dalam Penerapan Motif Batik Klasik.Prabangkara. 14. (17) : 73-81 